the disease in his own person; and on this ground the recommendation to mercy was fully justified. The prisoner then was most properly found guilty, and at most is only entitled to such mitigation of punishment as the court may think proper to grant under the circumstances. But the judges seem to have misunderstood the verdict, which surely is something widely different from an acquittal; and though an acquittal on the ground of insanity entails detention for life in the dreary abode provided for the so-called criminal lunatics, there is something wanted as a direct punishment for these half-mad assassins, which will appeal more forcibly to their fears than the horrors of the criminal department of Bethlehem, which are not realised, but, on the contrary, regarded as a very tolerable penance when the alternative is the scaffold. If, as in this case, the murderer knew that it was wrong to slay his victim, why should he and others of the same class not be tanght that, while every allowance is made for any mental defect, this is not to screen them from the cousequences of their unrestrained passions? In France, such offenders would be condemned to hard labour for life, and why should not the same principle be adopted here. From the remarks of the judges, it seems probable that Westron will be dealt with as if he had been acquitted on the ground of insanity; but it ap. pears to me that before he can be legally committed to the cri minal department of Bethlehem, he must receive the Queen's pardon, for no criminal is sent there avowedly for punishment; and Westron having been found guilty of murder, must surely undergo some punishment, unless he be pardoned. There is one point in the evidence which cannot fail to arrest the attention of those who have taken an interest in this question of criminal lunacy; it is the necessity under which the witnesses and jury felt themselves to frame their evidence and verdict so as to meet the judicial view of mental unsoundness. One of the medical witnesses, a highly respectable practitioner, is made to contradict himself, by saying first that he considered the accused "at the time he shot Mr. Waugh, incapable of distinguishing between right and wrong ;" and immeliately afterwards, in answer to a question from the judge whether "he thought the prisoner was in such a state as to his nind, as to be incapable of knowing it was wrono to kill a man," he replied, that " perhaps he could not go that length; but he inferred from all that had taken place, that he was at the time incapable of distinguishing between right and wrong." The witness seems to have felt, when the question was clearly put by the judge, that he could not conscientiously say that the prisoner was incapable of knowing that it was wrong to kill a man; he evidently felt that the prisoner's mind was to some extent unsound, but that no notice would be taken of this unless it could be stated to be so mnsound as to meet the legal view of the question. Why shonld a witness be placed in such a dilemma that he must either twist his evidence into a certain required form, or make himself a party to the execution of a person of unsound mind? Surely the judges thernselves must be convinced by this time that their exposition of the law on this question is unsomnd, for it has signally failed whenever it has been applied.

It is in direct opposition to the experience of all who have had the charge of the insane, to assert that an insane person does not know the difference between right and wrong. The whole treatment of insanity is based upon the supposition that they $\mathrm{do}$, and accordingly the same motives are held out for them to exercise self-control that are known to influence sane persons, with of course various degrees of success, but always with some, excepting in cases of absolute imbeciity. There are few questions of domestic policy more worthy of the serious attention of the legislature than criminal lunacy as it is called, and it is to be hoped that the law on this subject will not be allowed much longer to remain in its present most unsatisfactory state, both as regards the plea of insanity and the management of criminal lunatics, who continue to be huddled together, without any reference to their crimes, their mental condition, or their social position.

I am, Sir, your obedient servant,

Upper Harley-street, Carendish-square. WM. WooD, M. D.

THE MEDICAL PROFESSION BILL.-MEDICAL FEES.

To the Editor of THE LANCET.

STR, - On perusing the Medical Bill at the present time before the House, I have been struck with the absence of any allusion to Medical Fees, a subject which, I am sure, requires attention. There is the greatest difference in the charges for medi- cine visits, and attendance in different districts ; and, if one uniform scale of fees could be introduced, (as in the legal profession, I am sure a great deal of annoyance and ill-feeling would be put an end to, as well as the uncertainty which seems to reign supreme among the county court judges, as to what constitutes a "reasonable" charge. In some places, "visits" are duly charged and paid for, while in others, less favoured, sich an item would at once be disallowed, of course aiding very materially to the work of the practitioner, and to the length of his shoemaker's bill. As a constant reader of THE LANCET for many years, I feel assured that a word therein will have its due effect, and, begging your powerful aid,

Hatfield, March, 1856 .

I remain, sir, youx obedient servant,

* * This letter contains a useful suggestion. It has already been contemplated by the authors of the Bill, to give the council a power to fix the rate of fees; and we have reason to believe that a clause for that purpose will be introduced in cormmittee. F. I. I.

\section{PAYMENT OF POORLAW SURGEONS.}

(LETTER FROM DR. JOSEPH PEARSON.)

To the Wditor of THE LANCET.

SrR,-Having been, for some time, an attentive observer of the interest yon have taken in the welfare of the medical officers of Unions, and of the unceasing efforts you have made, through the medium of THE LANCET, to ghtain for them some alleviation of the oppression and injustice under which they labour, I have drawn up, in as few words as possible, a summary of a correspondence I have had with the Foor-law Board regarding the reduction of the salary of the medical officer of the Maryport district of the Cockemonth Union, thinking that you may deem it worthy of a place in your valuable periodical.

In April, 185. the Poor-law Bosrd proposed to the guardians to make certain alterations in the area and population of the different districts; this the guaruians resisted for some time, but at last fincling they had no alternative, they came to the resolution of dividing the four districts into five. I wrote to the Poor-law Board at that time, stating that the proposed alteration, so far as my district was concemed, could not possibly benefit the paupers, for they would still be as far as ever from the medical officer, at the same time pointing out to them that there were medical men residing within three miles of the places they proposed to remore. The guardions, however, accomplished their object, and they then determined to reduce the salaries of the medical officers from $£ 35$ to $£ 30$ per annum regardless either of the area on popnlation of the different districts. Of this I received no official intimation, either from the guardians or commissioners, but hearing privately from one of the guardians that such was their intention, I agin wrote to the Poor-law Board, inclosing a statement of the duties, and the remuneration $I$ had received for the last five years, showing, I thought, clearly enough to any unprejudiced person, that $I$ could have received rery little during that time for my professional services. In one year, after deducting all expenses, I received $£ 11$ Is. $6 d$., for which I attended thirty-six midwifery cases, three fractures, and one dislocation. I made 1786 visits, and travelled 1417 miles into the country. This allowed me $1 \frac{l}{d} d$. per visit, at whatever distance, and whether I attended a labour, or reduced a dislocation or fracture at the end of my journey. Not hearing from the Poor-law Board before the quarter's salary became due, and never having received any official notice that the salary had been reduced, $I$ sent in my bill at the old awount, $£ 35$. In clue time I received a cheque for the amount, minus $\& 15.5$, and was then told by the clerk, in his letter, that the guardians had reduced my salary to $£ 39$ per annum. I again wrote to the Poor-law Board complaining that I had been most unfairly treated, telling them that they must be well aware that I could recover the $£ l 5 s$. in a court of law, if I thought proper; for the transaction, if not dishonest, was clearly illegal. To the above I received no reply for nearly twelve months, and being very much occupied with my professional duties during the winter, I had little time to direct $\mathrm{my}$ attention to the subject until the summer of last year, when I again wrote to the Poor-law Board, begging them to tell me what my salary really was, referring them to their own order, fixing it at $\$ 35$ per annum; which order had never yet been rescinded by their board, which alone had that power. Consequently the contract never having been cancelled was still in force; at the same time referring them to a case reported in The Larcex, where the Judge of the County. Conrt decided 